Elena A. Czefranowa

\title{
Historyczne uwarunkowania regulacji małżeńskich stosunków majątkowych w prawie rosyjskim
}

\author{
Summary
}

Old Russian family law was based on system of separation of property between spouses. When Bolsheviks took power, they retained this system. They were claiming that separation of property between spouses is the best from the point of view of equality of husband and wife. The change was done in 1926, together with new Family Code. It imposed the system of joint community in matrimony. The official explanation was that it's the best system for women. In fact, this system was most of all convenient for Communist government, which planned huge industrialization of the country. Up till now, even after the fall of Communism, this system is retained.

Uregulowania prawne stosunków majątkowych małżonków w okresie przedrewolucyjnym wyróżniały się znaczną oryginalnością. Od dawna na Rusi kobieta zamężna miała prawo do posiadaniai dysponowania swoim majątkiem.Już w Sobornym Ułożeniju z XVII w. znajdowała się norma, według której „kupione dobra żony jego, swobodnie ona może na tych dobrach robić co zechce, nikomu nic do tego". Także Piotr I sprzyjał idei poprawy położenia kobiety rosyjskiej. Jego ukaz z 1715 r. dawał żonie prawo do swobodnego sprzedawania i zakładania swoich dóbr bez zgody męża. Według wybitnego cywilisty rosyjskiego przełomu XIX i XX w. G. F. Szerszeniewicza projekty kodeksu cywilnego z 1809 i 1814 r., które powstały o wiele wcześniej niż Zwód Praw Imperium Rosyjskiego, miały u swych podstaw system rozdzielności majątkowej. Zwód Praw Imperium Rosyjskiego ustalał zasadę rozdzielności majątkowej małżonków i przeprowadził ją dość konsekwentnie. G. F. Szerszeniewicz pisał: „Ustawodawstwo rosyjskie ustanawia pełną rozdzielność majątkową pomiędzy małżonkami. Małżeństwo nie czyni wspólności majątkowej małżonków, każde 
z nich może mieć i od nowa nabywać odrębną własność (t. 10, cz. 1, art. 109)1. Z zasady rozdzielności majątkowej wynikała możliwość dla każdego małżonka rozporządzania swoim majątkiem bezpośrednio w swoim imieniu, niezależnie od współmałżonka i bez zgody współmałżonka (t. 10, cz. 1, art. 114). Stąd też wynikało, że małżonkowie, jako samodzielne podmioty, mogli zawierać między sobą wszystkie możliwe umowy typu darowizn i inne o odpłatnym charakterze (t. 10, cz. 1, art. 116) ${ }^{2}$. Konsekwentne wprowadzenie w Zwodzie Praw zasady rozdzielności i, jako skutek tego, pełnej samodzielności majątkowej kobiety, autor wyjaśniał niczym innym, jak odzwierciedleniem rosyjskich obyczajów i dodawał, że takie odejście prawodawstwa rosyjskiego od wzorców zachodnich stanowi zagadkę $\mathrm{w}$ historii prawa rosyjskiego ${ }^{3}$. Według opinii G. F. Szerszeniewicza „ustalona przez zachodnie ustawodawstwa wspólność majątkowa wynika historycznie $\mathrm{z}$ osobistego podporządkowania żony mężowi”, a nie $\mathrm{z}$,idei zgodności kontaktów majątkowych z kontaktami osobistymi i moralnymi wynikającymi z małżeństwa”. „W rzeczywistości - kontynuował swoją myśl Szerszeniewicz - niesamodzielność majątkowa kobiety zamężnej ustanowiona w większości współczesnych ustawodawstw zachodnioeuropejskich, opiera się nie na idei małżeństwa, a na prawie osobistej władzy męża nad żoną, z którym mało zgodna byłaby niezależność majątkowa. Jeżeliby wspólność majątkowa opierała się na stosunkach małżeńskich, to prawa obu małżonków byłyby równe, gdy tymczasem wszędzie mąż zarządza wspólnym majątkiem" ". Obowiązujący w Rosji system rozdzielności dawał kobiecie wielką samodzielność nie tylko w porównaniu z systemami ogólnej wspólności majątkowej oraz wspólności majątku ruchomego i nabytego, ustanowionymi w Europie kontynentalnej, ale i zasadniczo różnił się od rozdzielności przyjętej w państwach common law. Kobieta w Rosji miała prawo zarządzać należącym do niej majątkiem, włączając posag. N. Reinke $\mathrm{w}$ związku $\mathrm{z}$ tym zauważył, że prawo po raz pierwszy $\mathrm{w}$ tej kwestii zawierało kategoryczne stwierdzenia: majątek żony nie tylko nie był własnością męża, ale - niezależnie od sposobu i czasu jego nabycia (w czasie trwania małżeństwa czy przed jego zawarciem) - mąż poprzez małżeństwo nie nabywał nawet prawa do korzystania z majątku żony ${ }^{5}$.

${ }^{1}$ G. F. Szerszeniewicz, Kurs grażdanskogo prava, Tuła 2001, s. 568.

${ }^{2}$ Normy Zwodu Praw przytaczam na podstawie polskiego przekładu: Z. Rymowicz, W. Święcicki, Prawo cywilne Ziem Wschodnich, t. 10, cz. 1 Zwodu Praw Rosyjskich. Tekst podług wydania urzędowego z roku 1914, z uwzględnieniem zmian, wprowadzonych przez ustawodawce polskiego, oraz ustawy zwiazkowe, tudzież judykatura Sąu Najwyższego i b. Senatu rosyjskiego, t. 1, Warszawa 1932.

${ }^{3}$ G. F. Szerszeniewicz, op. cit., s. 561.

${ }^{4}$ Ibidem, s. 558.

${ }^{5} \mathrm{~N}$. Renke, Dviżenije zakonodatielstva ob imuszczestviennych pravach zamużnich żenszczyn, „Żurnał Grażdanskogo i Ugolovnogo Prava", Sankt-Petersburg 1884, t. 3, s. 69-70. 
Stosunek przedrewolucyjnych uczonych-cywilistów do prawnych uregulowań małżeńskich stosunków majątkowych na zasadzie rozdzielności nie był jednoznaczny. D. Azarewicz, A. Zagorowski, I. Orszanski podkreślali negatywne strony systemu rozdzielności, twierdząc że rozdzielność majątkowa małżonków jest sprzeczna $\mathrm{z}$ ideą ich wspólnego pożycia i interesów majątkowych. G. Szerszeniewicz, D. I. Mejer, K. Pobiedonoscew uważali system rozdzielności ustalony przez Zwód Praw za postępowy, gdyż - ich zdaniem - gwarantował on niezależność ekonomiczną kobiety i, co z tym jest ściśle związane, jej równość z mężem w rodzinie ${ }^{6}$. Broniąc idei rozdzielności majątkowej, G. F. Szerszeniewicz pisał: „Z prawnego pojęcia o małżeństwie i uznaniu wolności jednostki każdego obywatela, niezależnie od przynależności do klasy społecznej i płci wynika, że w stosunkach osobistych i majątkowych małżonkowie powinni być tak samo równi i samodzielni, jakimi byli przed zawarciem małżeństwa. Małżeństwo nie powinno mieć żadnego wpływu na status małżonków, których stosunki prawne powinny być takie jak między osobami postronnymi. (...) Kobieta $\mathrm{w}$ rodzinie powinna korzystać $\mathrm{z}$ takiego samego statusu prawnego, z jakiego korzystała przed zawarciem małżeństwa i z jakiego będzie korzystać po ustaniu małżeństwa. Powinna posiadać także samodzielność majątkową. Jeżeli w rodzinie faktycznie powstaje wspólny fundusz w postaci warunków domowych i środków pieniężnych przeznaczanych na potrzeby bieżące, to jest to możliwe i rzeczywiście ustalane jest pomiędzy osobami postronnymi w przypadku wspólnego zamieszkania. Ale takie stosunki nie mają dużego znaczenia prawnego, tym bardziej, że one zachowane są do chwili, kiedy pomiędzy małżonkami nie powstają niesnaski. Interes prawny w kwestii uznania rozdzielności majątkowej dotyczy nieruchomości, kapitału nie podlegającego faktycznemu połączeniu i zapewniającego samodzielność materialną każdego z małżonków"7.

Jednocześnie nie było żadnych przeszkód do zawarcia między małżonkami umowy małżeńskiej i wyboru systemu wspólności majątkowej lub innego systemu znanego w krajach zachodnich i ich systemach prawnych ${ }^{8}$.

W sposób szczególny należy wskazać na rozwinięty w tamtym czasie dyspozycyjny charakter uregulowań prawnych w zakresie stosunków majątkowych.

${ }^{6}$ G. F. Szerszeniewicz, op. cit.; D. I. Mejer, Russkoje grazdanskoje pravo (v 2-ch cz.), cz. 2, Moskva 1997; K. Pobiedonoscev, Kurs grazhdanskogo prava; D. Azarewicz, Semiejnyje imuszczestvennyje otnoszenija po russkomu pravu, „Żurnał Grażdanskogo i Ugołovnogo Prava”, Sankt-Petersburg 1883, t. 4; I. A. Zagorovskij, Kurs semejnogo prava, Odessa 1909; I. G. Orszanskij, Issledovanija po russkomu pravu semejnomu i nasledstvennomu, Sankt-Petersburg 1877.

${ }^{7}$ G. F. Szerszeniewicz, op. cit., s. 558. G. F. Szerszeniewicz, D. I. Mejer, K. Pobiedonoscew uważali system rozdzielności określony w Zwodzie za postępowy, gdyż według nich zabezpieczał on niezależność ekonomiczną kobiet i, co za tym idzie, jej pozycję w rodzinie na równi z mężem.

${ }^{8}$ D. I. Mejer, Russkoje grazdanskoje pravo, op. cit., s. 731-732, 734. 
W czasach radzieckich, wraz z przyjęciem w $1918 \mathrm{r}$. Kodeksu prawa o aktach stanu cywilnego, prawa małżeńskiego, rodzinnego i opiekuńczego ${ }^{9}$, wspólność majątkowa nie została wprowadzona, zachowały się natomiast normy o rozdzielności majątku małżonków. Ponadto małżonkowie mieli prawo zawierać między sobą wszystkie dozwolone umowy majątkowe ${ }^{10}$.

Godne uwagi jest to, że rewolucyjny ustawodawca zachował tradycyjny dla Rosji przedrewolucyjnej system rozdzielności majątkowej małżonków. Dopiero teraz został on utrwalony w normie imperatywnej (art. 105), w której była mowa o tym, że małżeństwo nie tworzy wspólnoty majątkowej małżonków, mąż nie ma prawa korzystać i zarządzać majątkiem żony i nie może otrzymać takiego prawa $\mathrm{w}$ wyniku umowy małżeńskiej. Majątek, niezależnie od tego, kiedy był nabyty - przed zawarciem małżeństwa lub w czasie trwania małżeństwa - uznawany był jako oddzielna własność każdego z małżonków. Małżonkowie nie odpowiadali swoim majątkiem za długi współmałżonka. Wszelkie transakcje jednego małżonka, godzące w interesy drugiego ze współmałżonków, uznawane były za nieważne. Zachowując pełną niezależność majątkową małżonków, prawo jednocześnie stwarzało możliwość zawierania między małżonkami transakcji o charakterze majątkowym, które nie byłyby sprzeczne z prawem. Wcielona została idea równości praw męża i żony, podkreślano ich pełną równość w stosunkach majątkowych. Zachowując zasadę pełnej rozdzielności majątkowej małżonków, która w nowych warunkach socjalnych „jest postępowa”, prawo wychodziło z punktu widzenia interesów kobiety, jej możliwości bycia niezależną w rodzinie ${ }^{11}$. Rozdzielność majątkowa małżonków w pełni odpowiadała głoszonej przez bolszewików równości płci. Lenin z dumą pisał: „Władza radziecka, jako władza ludu pracującego, w pierwszych miesiącach jej istnienia przeprowadziła w prawodawstwie zdecydowany przewrót, jeżeli chodzi o kobiety. Z wszystkich ustaw, które podporządkowywały kobiety, w Republice Radzieckiej nie zostało niczego"12.

Jednak kolejny Kodeks ustaw o małżeństwie, rodzinie i opiece RFSRR z 1926 roku $^{13}$ odszedł od zasady rozdzielności majątkowej małżonków i wprowadził system wspólności dorobku. Jednocześnie kodeks zawierałspecjalną normę, która pozwalała małżonkom na zawieranie pomiędzy sobą wszystkich dozwolonych przez prawo umów majątkowych. Oprócz tego przewidziana była zasada nieważności porozumień pomiędzy małżonkami, które godziłyby $\mathrm{w}$ prawa majątkowe żony lub męża. W art. 10 kodeksu z 1926 r. zamieszczono następującą regulację: „Majątek należący do małżonków przed zawarciem małżeństwa jest

\footnotetext{
${ }^{9}$ SU RSFSR 1918, nr 76-77, s. 818.

${ }^{10}$ A. M. Nieczajewa, Semejnoje pravo, Moskwa 1998, s. 68.

${ }^{11}$ N. M. Jerszowa, Imszczestvennyje pravootnoszenija v sem'je, Moskwa 1979, s. 10-11.

${ }^{12}$ W. I. Lenin, Polnoje sobranije soczinenij, t. 39, s. 199.
} 
ich odrębnym majątkiem. Majątek dorobkowy małżonków nabyty w czasie trwania małżeństwa jest wspólnym majątkiem małżonków. Wysokość udziałów każdego z małżonków w przypadku sporu określa sąd".

Postaramy się wyjaśnić prawdziwe przyczyny, dlaczego po upływie krótkiego, nawet według rewolucyjnych miar czasowych, okresu nastąpiła tak zdecydowana zmiana uregulowań prawnych stosunków majątkowych małżeńskich. Kodeks z 1926 r. nie tylko utrwalał wspólność majątkową małżonków, ale przy tym wyłączał możliwość zmiany ustalonego przez prawo ustroju majątkowego za pomocą umowy małżeńskiej. Czy rzeczywiście władza radziecka, wprowadzając wspólność majątkową małżonków za pomocą imperatywnego stwierdzenia, jak przyjęło się uważać w naszym prawie rodzinnym, troszczyła się o zabezpieczenie interesów kobiety-gospodyni domowej, nie mającej samodzielnego źródła dochodów i wskutek tego prawa do majątku w rodzinie? Kobieta zajmowała się gospodarstwem domowym i wychowaniem dzieci. Majątek nabywany był za pieniądze zarobione przez męża i uważany był za jego odrębną własność. $\mathrm{W}$ rezultacie w trakcie rozwodu żona mogła zostać bez majątku. Wprowadzenie ustroju wspólności w tym okresie było obiektywnie uwarunkowane przez wymienione okoliczności"14. Takie wyjaśnienie jest dość przekonywujące, ale tylko do momentu, kiedy rozpatrywana nowela nie jest analizowana $\mathrm{w}$ połączeniu $\mathrm{z}$ danymi demograficznymi i statystycznymi tamtych czasów, ogólnymi kierunkami polityki kraju - z jednej strony, a także w połączeniu z innymi zmianami kodeksu z 1926 r. i w ich porównaniu z normami kodeksu z 1918 r. - z drugiej strony.

Właśnie w 1926 r. został przeprowadzony pierwszy spis ludności ZSRR, który ustalił, że ludność kraju liczyła $147 \mathrm{mln}$, z czego 82\% stanowili mieszkańcy terenów wiejskich i tylko $18 \%$ zamieszkiwało miasta. Ludność RFSRR liczyła 100,8 mln, większość stanowiła ludność samodzielna, niezależna, przy czym samodzielne źródło środków do życia miało 65,05\% mężczyzn i 52,65\% kobiet $^{15}$. $\mathrm{O}$ jakich niesprzyjających dla niepracującej kobiety skutkach rozwodu możemy mówić, kiedy - po pierwsze - rozwód był rzadkością dla co najmniej 82\% ludności kraju? W 1926 r. na każdy tysiąc mężczyzn w kraju przypadało tylko 5 rozwiedzionych, a na każdy tysiąc kobiet - 12 rozwiedzionych (w 1989 r. ten wskaźnik wyglądał odpowiednio - 57 rozwiedzionych na tysiąc mężczyzn i 85 - na każdy tysiąc kobiet) ${ }^{16}$. Jak widzimy, przedstawiony wskaźnik wzrósł

${ }^{13}$ SU RSFSR 1926, nr 82, s. 612.

${ }^{14}$ Zob. M. V. Antokolskaja, Semejnoje pravo. Uczebnik, Moskwa 1996, s. 66 i 71; N. M. Jerszowa, op. cit., s. 11.

${ }^{15}$ K Dokladu CSU v Sovete Narodnych Komissarov ob itogach perepisi naselenija 1926 goda, Moskwa 1927, s. 9 .

${ }^{16}$ Naselenije Rossii za 100 let 1897-1997. Statistizheskij sbornik, Moskwa 1998, s. 77. 
11,4-krotnie dla mężczyzn i ponad 7-krotnie dla kobiet. Po drugie, chłopka nie była i nie mogła być kobietą niepracującą-gospodynią domową, jej wkład do dochodu rodziny chłopskiej, a nie zarobki, był ważki i znaczny. A więc o rozwodzie jako o rozpowszechnionym i społecznie znaczącym zjawisku, a tym bardziej o takim, w wyniku którego żona mogła pozostać bez majątku, mowy być nie mogło. Inne nowelizacje kodeksu - uznanie za małżeństwa par pozostających w stosunkach konkubenckich (rejestracja takiego związku miała skutki ex tunc) i nadzwyczajne uproszczenie procedury rozwodu, w wyniku którego rozwiązanie małżeństwa następowało na wniosek któregokolwiek z małżonków w urzędach stanu cywilnego, przy czym bez wzywania drugiego małżonka, niemożliwe jest do oceny jako odpowiadające interesom kobiety $\mathrm{w}$ ogóle, a kobiety-gospodyni domowej tym bardziej. To potwierdza naszą hipotezę: ustawodawca wcale nie kierował się interesami niepracującej kobiety przy zamianie ustroju rozdzielności na ustrój wspólności majątkowej małżonków. Motywem takiej decyzji było dążenie do przyspieszenia priorytetu form społecznych $\mathrm{w}$ działalności ludzi, ograniczenie do minimum sfery prywatnej $\mathrm{w}$ życiu obywatela. Wpływanie na światopogląd, moralność, tryb życia powszedniego i gospodarczego narodu rosyjskiego i naturalnie na rodzinę, prowadzone było we wszystkich kierunkach. Wystarczy wspomnieć filary patriarchalnej Rosji, w tym również rodzinę jako tradycyjną wartość, która była niszczona w sposób aktywny i ukierunkowany, przede wszystkim na skutek prowadzonej przez bolszewików polityki ekonomicznej. Socjalizm od samego początku oznaczał zniesienie własności prywatnej. Kiedy ludziom zostaje odebrana należąca do nich własność, to tym samym są oni pozbawieni niezależności od państwa. Pomiędzy prywatną własnością i istnieniem społeczeństwa obywatelskiego istnieje, jak wiadomo, ścisły związek. Zniesienie własności prywatnej oznacza zniszczenie społeczeństwa obywatelskiego. W latach komunizmu wojennego wszystkie warstwy społeczeństwa obywatelskiego albo zostały zlikwidowane (szlachta i różne warstwy burżuazji), albo znalazły się w orbicie wpływów państwa (np. pozostałości bardzo zredukowanej klasy robotniczej). Wyjątek stanowiła ogromna warstwa chłopów. Przy pomocy przymusowej kolektywizacji $\mathrm{i}$ industrializacji $\mathrm{w}$ ramach pierwszego planu pięcioletniego partia-państwo w drugiej próbie wchłonęła i w całości zlikwidowała społeczeństwo niezależne od państwa ${ }^{17}$.

Znamienne jest to, że Kodeks małżeński, rodzinny i opiekuńczy został zatwierdzony postanowieniem Wszechrosyjskiego Centralnego Komitetu Wykonawczego z 19 listopada 1926 r. Kilka dni przed tym faktem, czyli

${ }^{17}$ Sovetskoje obszchestvo: vozniknovenije, razvitije, istoriczeskij final, t. 2, J. N. Afanasjew (red.), Moskwa 1997, s. 578-579. 
3 listopada 1926 r., na XV partyjnej konferencji, poświęconej problemom polityki ekonomicznej, nie tylko został zaakceptowany i przyjęty przez XIV Zjazd WKP(b) w grudniu 1925 r. „kurs na industrializacje”, ale i postawione zostało zadanie dogonienia $\mathrm{w}$ możliwie krótkim czasie, a następnie przekroczenie poziomu rozwoju przemysłowego przodujących krajów kapitalistycznych ${ }^{18}$. „Linia generalna” partii i państwa wymagała ogromnych nakładów kapitałowych, które należało znaleźć poprzez likwidację dotychczasowego porządku, upaństwowienie wszystkich sfer ekonomiki, nagłe zwiększenie przez państwo eksploatacji ludu pracującego. Wieś została uznana za siłę pomocniczą industrializacji, za źródło tanich zasobów. Bardzo intensywne uprzemysłowienie i całkowita kolektywizacja były dwiema stronami jednego kursu, skierowanego na tworzenie niezależnego mocarstwa wojskowo-przemysłowego z maksymalnie upaństwowioną gospodarką i nie mającym żadnych praw, na poły biednym narodem. Kolektywne zarządzanie państwem rozpatrywane było $\mathrm{w}$ charakterze podstawowej dźwigni przepompowującej ze wsi środki dla industrializacji i ręce do pracy dla nowych fabryk, zakładów i kopalni. Na podstawie spisu ludności ZSRR w 1939 r. przy ogólnej liczbie ludności 176,6 mieszkańców już 33\% mieszkało w miastach (podczas gdy w 1926 r. tylko $18 \%)^{19}$.

Dymitr I. Kurski z powodu ustroju majątkowego małżonków pisał: „Małżeństwo w ustroju radzieckim stanowi przede wszystkim związek dwóch pracujących [tutaj i dalej pokreślenie moje - E. A. Czefranowa], gdzie nie ma możliwości podziału, co z ogólnego majątku w tym związku i przez kogo zostało zapracowane i wniesione do wspólnego użycia. Dlatego ze strony prawnej podyktowana jest konieczność uznania wspólności praw każdego z małżonków do wszystkiego, co zostało nabyte przez nich w czasie wspólnego pożycia..., nie podejmując się jawnie beznadziejnego i zasadniczo nieprawidłowego zadania uwzględnienia i rozdzielenia tego, co $\mathrm{w}$ jakim stopniu i przez którego z małżonków zostało wniesione do wspólnego dorobku”"20. W tej dosyć szczerej wypowiedzi komisarza ludowego sądownictwa RSFRR, członka CKK, członka Prezydium WCIK i CIK ZSRR dopatrujemy się istoty polityki rodzinnej państwa radzieckiego. Po pierwsze, o żadnej żonie-gospodyni domowej nie mogło być mowy, gdyż małżeństwo było postrzegane jako związek dwojga pracujących osób: „wyzwolenie kobiety” następowało tylko w celu zwiększenia zasobów pracowniczych $^{21}$, kobiecych rąk pilnie potrzebowała gospodarka narodowa,

${ }^{18}$ Ibidem, s. 669.

${ }^{19}$ A. S. Orłow, V. A. Georgijew, A. J. Połunow, J. J. Treszczenko, Osnovy kursa istorii Rossii, Moskwa 1999, s. 500-509.

${ }^{20}$ D. I. Kurskij, Izbrannyje stat'i i reczi, Moskwa 1958, s. 269-270.

${ }^{21}$ O. V. Dorochina, Issledovanije politiki gosudarstva v otnoszenii sem’i, „Sem’ja v Rossii” 1997, nr 2, s. 22. 
szybko więc rosło zatrudnienie kobiet. Po drugie, zarobki są wskazywane jako jedyne źródło nabywanego majątku, o uzyskaniu innych dochodów nie było i nie mogło być mowy, albowiem „kto nie pracuje, ten nie je”. Po trzecie, majątek przeznaczony był wyłącznie na zaspokojenie potrzeb konsumenckich poprzez wspólne użytkowanie. Uwzględniając wyjątkowo niski poziom życia większości radzieckiego ludu pracującego, którego podstawowym źródłem utrzymania były zarobki w przemyśle, bliskie minimum życiowemu, i prawie symboliczna zapłata za dniówkę w kołchozie, należy zgodzić się z autorem, że zadanie podzielenia tego, który z małżonków i co wniósł, było zadaniem beznadziejnym. Interesujące jest to, że autor uważa to zadanie dodatkowo za zasadniczo nieprawdziwe. $\mathrm{W}$ istocie - rozdzielność majątkowa małżonków usprawiedliwiona jest tam, gdzie istnieje własność prywatna, niezależność i samodzielność równoprawnych i wolnych w swoim wyborze małżonków. Według G. F. Szerszeniewicza „interes prawny uznania rozdzielności majątkowej dotyczy nieruchomości, kapitałów nie podlegających faktycznemu połączeniu i zapewniających samodzielność materialną każdego z małżonków"22. Należy przyznać, że tam, gdzie nie ma prywatnej własności, a jakikolwiek przejaw samodzielności i niezależności jednostki od państwa jest dławiony i niszczony, nie ma miejsca także dla ustroju rozdzielności majątkowej małżeńskiej, jak też nie ma miejsca dla umowy małżeńskiej - prywatnego przejawu wolności wyboru.

Na podstawie tego, o czym wcześniej była mowa, możemy wyprowadzić jedyny możliwy wniosek: wprowadzenie ustroju wspólności małżeńskiej było podyktowane logiką budowania radzieckiego ustroju socjalistycznego. „Nasze” wypierało „moje” ze wszystkich bez wyjątku stosunków majątkowych, w tym również, co jest zrozumiałe, ze stosunków majątkowych, jakie kształtowały się w rodzinie. Całkowity brak wolności jednostki w państwie i społeczeństwie był w sposób naturalny uzupełniony zależnością majątkową w rodzinie. Zupełnie oczywiste jest to, że wybrana reglamentacja prawna stosunków majątkowych $\mathrm{w}$ rodzinie określona była przez czynniki o charakterze politycznym i ideologicznym. Niektórzy autorzy byli w wielkim błędzie, uważając wprowadzenie wspólności majątkowej małżonków jako środek czasowy i niezbędny do tego momentu, dopóki kobieta nie będzie równa $\mathrm{z}$ mężczyzną $\mathrm{w}$ sferze stosunków ekonomicznych. Do nich należał Hans Natan, który przypuszczał, że „w społeczeństwie, w którym jest pełen socjalizm (...) w charakterze zasady powinna być ustalona rozdzielność majątkowa"23.

Zasada wspólności majątku, który został zgromadzony w czasie trwania małżeństwa i odrębna własność majątku należącego do małżonka przed

\footnotetext{
${ }^{22}$ G. F. Szerszeniewicz, op. cit., s. 558.

${ }^{23}$ G. Natan, Nekotoryje mysli po povodu imuszczestvennych prav suprugov v socjalistyczeskom obszchestve, [w:] Gosudarstvo i pravo v svete Velikogo Oktiabra, Moskwa 1958, s. 268-269.
} 
zawarciem związku, była przyjęta przez kolejne radzieckie ustawodawstwo. Została utrwalona też w Zasadach ustawodawstwa ZSRR o małżeństwiei rodzinie, które weszły w życie z dniem 1 października $1968 \mathrm{r}^{24}$, a także w przyjętych na ich bazie Podstawach kodeksów małżeńskich i rodzinnych republik związkowych oraz w Kodeksie małżeńskim i rodzinnym RFSRR z 1969 r., który wszedł w życie z dniem 1 listopada $1969 \mathrm{r}^{25} \mathrm{~W}$ kodeksie małżeńskim i rodzinnym RFSRR z 1969 r., w odróżnieniu od kodeksu z 1926 r., nie było normy zezwalającej małżonkom na zawieranie transakcji między sobą. Nawiasem mówiąc, nie ma takiej normy także w Kodeksie rodzinnym Federacji Rosyjskiej z 1996 r. Brak norm o transakcjach pomiędzy małżonkami tłumaczony jest tym, że były to w praktyce bardzo rzadkie przypadki. W literaturze pojawiają się jednak poglądy, że porozumienia małżonków nie mają cech umowy, są szczególnym rodzajem aktów prawnych uwarunkowanych specyfiką stosunków prawnych w rodzinie ${ }^{26}$. Jednakże osobliwość przedmiotu i metod prawa rodzinnego nie oznacza, że małżonkowie nie mają prawa zawierać między sobą transakcji cywilnoprawnych o charakterze majątkowym ${ }^{27}$.

Uczeni $\mathrm{z}$ dziedziny radzieckiego prawa rodzinnego wypowiadali się jednomyślnie za ogólną wspólną własnością małżonków. Tak więc, K. A. Grawe pisał: „Jeżeli chodzi o środek umocnienia faktycznej równości kobiet i mężczyzn, ich stosunki w coraz większym stopniu budowane są na podstawie wzajemnego zaufania, które wyłącza możliwość skrupulatnego podliczania wzajemnych wkładów do majątku rodziny, dlatego zasada wspólności majątku małżonków została utrwalona w ustawodawstwie radzieckim"28. Z takim poglądem zgadzała się także N. M. Jerszowa: „Odrodzenie się w rodzinie rozdzielności majątkowej małżonków nie będzie wspomagać oczyszczenia stosunków rodzinnych zrozliczeń materialnych, pomagaćwwychowaniu w rodziniewspólnychinteresów, zarówno osobistych, jak i majątkowych. Wspólność majątkowa małżeńska - to zasada, która nie tylko ma głębokie korzenie, ale i w perspektywie będzie określać sferę majątkową rodziny. Podstawą wspólności majątkowej jest majątek zdobyty pracą, zarówno w warunkach współczesnych, jak i w perspektywie rozwoju rodziny radzieckiej”29. Ponadto normy prawa rodzinnego, dotyczące wspólnej własności małżonków i stanowiące jądro stosunków małżeńskich majątkowych, stawiane były na pierwszym miejscu wśród innych środków ochrony prawnej

${ }^{24}$ VVS SSSR 1968, $\mathrm{nr} 27$, s. 241.

${ }^{25}$ VVS RSFSR 1969, nr 326, s. 1086.

${ }^{26}$ V. F. Jakowlew, Grażdansko-pravovoj metod regulirovanja obszczestvennych otnoszenij: Uczebnoje posobije, Swierdłowsk 1972, s. 162.

${ }^{27}$ E. A. Czefranowa, Sdielki, zakluczajemyje mezdu suprugami, „Juridiczeskij Mir” 2003, nr 12, s. 45 .

${ }^{28}$ K. A. Grawe, Imuszczestvennyje othoszenija suprugov, Moskwa 1960, s. 31-35.

${ }^{29} \mathrm{~N}$. M. Jerszowa, op. cit., s. 12-15. 
rodziny. Zasada małżeńskiej wspólności majątkowej rozpatrywana była jako skierowana wprost w celu umocnienia przede wszystkim rodziny, gdyż wszystko, co zostało nabyte $\mathrm{w}$ trakcie trwania małżeństwa jest wspólne, niezależnie od wysokości bezpośrednich wkładów materialnych małżonków ${ }^{30}$.

Niektórzy autorzy w dążeniu do umocnienia rodziny za pomocą środków prawnych posunęli się jeszcze dalej sądząc, że w warunkach budowy społeczeństwa komunistycznego nie ma podstaw do dzielenia majątku na "twoje” i „moje”. Proponowano, aby cały majątek małżonków, zarówno posiadany przed zawarciem małżeństwa, jak i dorobkowy, uznawać za majątek wspólny ${ }^{31}$. Jednak wpływ norm prawnych na stałość stosunków małżeńskich według prawników był przesadny, o czym świadczą wyniki przeprowadzonych badań ${ }^{32}$. Środki prawne, służące umocnieniu rodziny, okazały się mało efektywne. W ciągu prawie trzydziestu lat małżeństwo było rozwiązywane, jeżeli sąd ustalił, że dalsze wspólne pożycie małżonków i zachowanie rodziny jest niemożliwe (cz. 3 art. 33 Kodeksu RFSRR). Sąd miał obowiązek podejmowania czynności zmierzających do doprowadzenia do zgody między małżonkami i odroczenia rozpatrzenia sprawy o rozwiązanie małżeństwa oraz wyznaczenie terminu w celu pojednania w ciągu sześciu miesięcy (art. 33 ust. 2 Kodeksu RFSRR) ${ }^{33}$. Nie zważając na to, krzywa rozwodów w Rosji wciąż rosła, o czym dobitnie świadczą liczby. Na każdy tysiąc ludności w 1970 r., czyli tuż po wejściu w życie Kodeksu małżeńskiego i rodzinnego RFSRR, przypadały 3 rozwody, w 1980 - 4,2, w 1990 - 3,8, w 1995 $-4,5$, a w $1999-3,7^{34}$.

Kodeks rodzinny Federacji Rosyjskiej ${ }^{35}$, który wszedł w życie z dniem 1 marca 1996 r., regulując stosunki majątkowe między małżonkami, wprowadził poważne zmiany w porównaniu z kodeksem RFSRR z 1969 r. Jednakże obowiązujący od 1926 r. ustrój wspólności małżonków w trakcie ostatniej kodyfikacji ustawodawstwa rodzinnego został zachowany $\mathrm{w}$ charakterze ustawowego małżeńskiego ustroju majątkowego.

${ }^{30}$ Pravo i zaszczita sem'i gosudarstvom, Moskwa 1987, s. 47.

${ }^{31}$ P. J. Orłowskij, K voprosu o razdelnom i obszczem imuszczestve suprugov po sovetskomu pravu, „Vestnik Moskovskogo Universiteta” 1966, Pravo, nr 6, s. 11; J. M. Worożejkin, Semejnyje pravo-otnoszenija v SSSR, Moskwa 1972, s. 62.

${ }^{32}$ A. B. Sinielnikow, Perspektivy izmenienija norm bracznosti i razvodimosti $v$ Rossijskoj Federacji, „Sem'ja v Rossii” 1997, nr 2, s. 12-17.

${ }^{33}$ Zob. p. 6 postanovlenija Plenuma Verchovnogo Suda RSFSR ot 21 fevrala 1973 goda, nr 3 „O nekotorych voprosach, voznikszych v praktikie primenienija sudami Kodeksa o brakie i sem'je RSFSR" i p. 11 postanovlenija Plenuma Verchovnogo Suda SSSR ot 28 nojabra $1980 \mathrm{~g}$.

${ }^{34}$ Zenszczyny i muzczyny v Rossii. Kratkij statisticzeskij spravocznik, Moskwa 2000, s. 30.

${ }^{35}$ SZ (Svod zakonov) RF z 1996 r., nr 1, poz. 16. 